\title{
Pre-invasion economic assessment of invasive species prevention: A putative ambrosia beetle in Southeastern loblolly pine forests
}

\begin{abstract}
Invasive wood borers vectoring pathogenic fungi have nearly exterminated several North American tree species, and it is unclear whether landscape dominant trees, such as pines, will face similar threats in the future. This paper explores the economic impacts of a hypothetical arrival of a destructive ambrosia beetle "X" (Coleoptera: Curculionidae) that infests loblolly pine (Pinus taeda L.) forests in the Southeastern United States. We develop an economic framework for pre-invasion assessment that incorporates fluctuating economic and environmental conditions for a representative loblolly pine stand and biological assumptions from the ongoing laurel wilt epidemic. Assuming an initial annual probability of arrival of a pine infesting ambrosia beetle to be between 0.04 and 0.07 , we determine that, on average, the timber economic benefits for a forest landowner are $\$ 5325.3 \mathrm{ha}^{-1}$, with a harvest time of 17.8 years. Our results indicate that an increase in enforcement consistent with an international phytosanitary standard that partially prevents the arrival of ambrosia beetles (30\% arrival reduction) would have a strong, positive impact for forest landowners. On average, economic revenues increase to $\$ 6116.4 \mathrm{ha}^{-1}$ and the harvest age is extended to 19 years. On average, the economic losses for forest landowners with no control of ambrosia beetle $\mathrm{X}$ would be $\$ 791 \mathrm{ha}^{-1}$, with a harvest time reduction of 1.2 years. The upper-bound regional cost savings from pine-dominated forestry would be roughly $\$ 4.6$ billion dollars if invasion preventative measures are in place. These benefits vastly outweigh the cost of programs that reduce the expected arrival of exotic ambrosia beetles.
\end{abstract}

Keywords: invasive species, pre-invasion; International Phytosanitary Standard, ambrosia beetle; net present value. 


\section{Introduction}

Invasive species - exotic species whose introduction causes economic harm, or harm to human health or the environment (U.S. Congress Office of Technology Assessment 1993) - can cause significant disturbance in natural, agricultural, and built environments; hinder critical ecological functions; and erode valuable ecosystem services (Adams and Lee, 2013; Lee et al., 2009). Once established, invasive species have the potential to cause catastrophic damage if left unchecked, and require significant and consistent efforts to actively manage. Nationally, it is estimated that

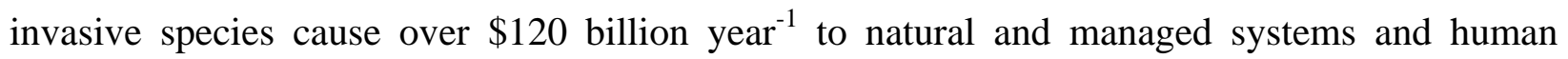
health, excluding impacts on several important ecosystem services and functions (e.g., biodiversity, endangered species habitat, aesthetics; Pimentel et al., 2005).

Most new exotic species introductions happen unintentionally as a result of international trade and travel (Keller and Perrings, 2011). From 2000-2010, roughly 2200 exotic species were brought into the U.S. via trade, and approximately 300 are known or potential invaders or pose significant disease risks (Keller and Perrings, 2011). However, the vast majority of exotic species introduction are benign. A 'tens rule' has been empirically observed, according to which approximately $10 \%$ of exotic species are expected to establish in natural areas, and a further $10 \%$ of those are expected to be invasive (Houlahan and Findlay, 2004). To date there have been approximately 50000 exotic species introduced to the U.S., with a relatively small proportion (around 800 species) causing noticeable damages (Pimentel et al., 2005).

In the case of invasive beetle species that can attack U.S. forests, and given current and expected trade flows, Koch et al. (2011) estimate that approximately every 5-6 years, one new alien-forest insect species will result in significant ecological or economic damage in the U.S. Furthermore, the same study finds that recent growth of Asian imports is accelerating projected 
establishment rates of invasive species in several major urban areas. Over the past 30 years, the U.S. has experienced other such alien-forest insect species that have caused severe ecological or economic damage: emerald ash borer (Agrilus planipennis Fairmaire), and the Asian longhorned beetle (Anoplophora glabripennis Motschuslky (Aukema et al., 2010).

The recent arrival of redbay ambrosia beetle, Xyleborus glabratus Eichhoff (Coleoptera: Curculionidae: Scolytinae \& Platypodinae), vectoring the deadly laurel wilt fungus Raffaella lauricola T.C. Harr. ${ }^{1}$ from Asia, ${ }^{2}$ has led to over $90 \%$ tree mortality of redbay trees (Persea borbonia (L.) Spreng) and significant losses in avocado (Persea americana), sassafras (Sassafras albidum (Nutt.) Nees), and swampbay (Persea palustris (Raf.) Sarg.) in the coastal planes of Georgia, Florida, Alabama, Mississippi, South Carolina, and North Carolina (Spiegel and Leege, 2013). From 1985 to 2005, at least 27 ambrosia beetles from Asia have been reported as established in the continental U.S. (North American Xyleborini, 2015). There are over 3500 species of ambrosia beetles in the world's forests. The vast majority of them occur in tropical or subtropical forests outside of the U.S., and thus presents a reservoir of potential invasive pests about which nearly nothing is known. In addition, the U.S. trade relations with Asian countries that are part of the native ambrosia beetle range are expected to grow significantly under the forthcoming Trans Pacific Partnership agreement (Shear, 2015). As a consequence, the rate of

\footnotetext{
${ }^{1}$ Ambrosia beetles bore tunnels (galleries) into trees, where they plant a symbiotic fungus that is "farmed" for sustenance (Mann et al., 2011; Sobel et al., 2015). These galleries are used to lay eggs by females, and all feed exclusively on the fungi (Hulcr et al., 2007).

${ }^{2}$ In its native Asian range (e.g., China, India, Bangladesh, Japan, Myanmar, Taiwan), the redbay ambrosia beetle only attacks dead or dying trees (Hulcr et al., 2007; Mann et al., 2011).
} 
introduction of invasive species to the U.S. from Asian trading partners is likely to increase, and it is also likely that other ambrosia beetles will become established in North America (Rabaglia et al., 2006).

There are ambrosia beetles in Asia that are specific to pines, but it is not yet known if they can affect U.S. pine trees (Bateman et al., 2014). Most ambrosia beetles do not appear to have a host preference (i.e. they are broad generalists; Hulcr et al., 2007), but in reality, little is known about host-specificity of most species (Hulcr and Lou, 2013). The most damaging one (Xyleborus glabratus) is a host specialist. Should one such species prove to be a pest specialized on trees that dominate the Southeastern landscape, such as pines, its introduction would have serious consequences for U.S. forests that support a multi-billion dollar timber products industry.

Once established, there are no known biological or physical deterrents that can feasibly prevent the spread of a hypothetical ambrosia beetle pest (Hanula and Mayfield, 2014; Maner et al.,2013) Maner et al. (2013) analyzed the use of a mesh screening around potential host trees, with the intention of creating a physical barrier that prevents access to the tree. Their results indicate that physical protection of trees by screening lower portions of the bole was not effective for ambrosia beetle. Current methods for the prevention of future imports of exotic insects decrease the infestation of wood in commercial shipping, but do not completely eliminate it. For example, wood packaging material (WPM), a major pathway for insects, is usually heat treated, but ambrosia beetles easily infest logs with bark even after heat treatment (Haack and Petrice, 2009). Another pre-invasion assessment tools include sentinel gardens. Roques et al. (2015) planted non-native (European) trees in Asia to serve as early warning tools that identify potential insect pest invaders. Their sentinel garden approach has so far yielded thirty-eight species that could be capable of switching to European trees if introduced to Europe. 
On a regulatory level, the U.S. has implemented two major efforts to prevent new introductions of wood-infesting insects since the early 2000s, relying on early detection and rapid response: 1) the USDA Forest Service Early Detection and Rapid Response (EDRR) program; and 2) the International Phytosanitary Standard (ISPM 15). The EDRR program for non-native bark and ambrosia beetles was first implemented in 2007 and includes multiple state and federal agencies (e.g., Forest Service, APHIS, universities, and state representatives). Its purpose is to develop a framework for early detection, monitoring, and responding to said infestations. In response to concerns of infested WPM serving as means of transport for woodfeeding invasive insects, the International Plant Protection Convention (IPPC), an international body representing the majority of U.S. trading partners (e.g., China, Japan, Mexico), adopted the ISPM 15 to reduce the risk of insect pest infestation (FAO, 2003). These standards provide specific treatments for WPM (e.g., heat treatments or methyl bromide fumigations) and were first implemented by the U.S. in 2005. Historical record analyses of pest interception rates, related to WPM inspected at U.S. ports, have indicated a modest reduction in WPM infestation rates, declining from $0.2 \%$ to $0.1 \%$ (around 36-52\% reduction) between 2003 and 2009 following the implementation of ISPM (Haack et al., 2014).

In this paper, we focus on the Southeastern U.S. region (Florida, Georgia, North Carolina, South Carolina, Virginia), which is roughly 60\% (35.1 million ha) covered by timberland, and provides approximately $28 \%$ of the nation's roundwood products (142.3 million $\mathrm{m}^{3}$ ) (Oswalt et al., 2014). The loblolly pine (Pinus taeda L.) is a native fast growing tree that is one the most important commercial species in the Southeastern U.S., occupying more than 6.3 million ha (Schultz, 1997). Therefore, the potential arrival of an ambrosia beetle that attacks loblolly pine stands, in a similar manner that redbay ambrosia beetle affects the Lauraceae tree 
family (redbay, avocado, swampbay, and sassafras), may lead to significant economic, ecologic, and cultural damages in the region.

No attempts have been made to gauge the economic damages and implications of a hypothetical invasive pest on the optimal pine forest management in the Southeastern U.S. To fill this gap, the specific objective of this study is to determine the partial economic impact of this hypothetical threat on a representative loblolly pine stand in the Southern U.S., by comparing two alternative scenarios: status quo (no additional control of a potential epidemic of a new ambrosia beetles), and a proactive scenario combining prevention and detection. We do this by analyzing: 1) the probability of arrival of an ambrosia beetle that attacks loblolly pine forest stands (ambrosia beetle X), causing lethal wilting; and 2) the economic impact of additional inspection policies with an effective deterrence rate of 30 and $100 \%$ prevention.

We introduce several novel approaches to determine the effects of forest disturbances beyond the traditional Reed approach (Reed, 1984): we model the expected impacts using a dynamic stand-level forest management simulation model, relax the assumption of constant annual probability of a natural disturbance, and incorporate stochastic stumpage prices - a component well explored in the literature (Brazee and Mendelsohn, 1988; Gong and Löfgren, 2007; Susaeta et al., 2009). These additions to the model allow us to address uncertainty and risk in key variables (arrival rates and stumpage prices). Assumptions about the conceptual epidemiology of ambrosia beetle $\mathrm{X}$ were inferred from the empirically observed epidemiology of an exotic ambrosia beetle that has already caused an epidemic among its host trees: the redbay ambrosia beetle and the pathogenic symbiotic fungus (Hanula and Mayfield, 2014). 


\section{Model specification and application to loblolly pine forest stands}

\subsection{Forest stand-level economic model}

In our stand-level simulation model, we assume that a forest landowner manages a forest stand to sell the timber at the harvest age and replants to start a new forest rotation ad infinitum, while facing the risk of stand destruction by ambrosia beetle $\mathrm{X}$. We define the time of arrival of ambrosia beetle $\mathrm{X}$ to a forest stand as an independent random variable $\varphi$, which follows a uniform distribution. The probability of arrival of ambrosia beetle $\mathrm{X}$ to a forest stand at a time $\varphi$, after a certain threshold time $t_{o}$ and before the harvest age $\mathrm{T}\left(t_{o} \leq \varphi<T\right)$, is $\operatorname{Pr}(\varphi)=1 /(x-$ $y$ ), $y \leq \varphi \leq x$, where $x$ and $y$ represent, respectively, the upper and lower arrival times of ambrosia beetle $\mathrm{X}$ with mean $\bar{\varphi}=(\mathrm{x}+\mathrm{y}) / 2$ and variance $\sigma_{\varphi}^{2}=(x-y)^{2} / 12 ; y \geq t_{o}, x<T$. The probability of arrival of ambrosia beetle $\mathrm{X}$ at harvest age $\mathrm{T}$ is $\operatorname{Pr}(\mathrm{T})=0$.

Given harvest age $T$, the age in which a stand is harvested, a forest landowner faces two states of the world. In the first, $G_{1}$, ambrosia beetle $\mathrm{X}$ arrives to the forest stand and causes a random damage, $\mu(\varphi)$, to the trees at time $\varphi$, before harvest age $T$. Once the damaged occurs, the landowner can salvage a random portion of the stand, $\omega(\varphi)=1-\mu(\varphi)$, and proceeds to replant the forest stand at $\operatorname{cost} C$, to begin a new rotation. The independent random damage $\mu$ and the random salvageable portion $\omega$ have means $\bar{u}$ and $\bar{\omega}$, respectively. The arrival of ambrosia beetle X may occur at different ages for each forest rotation. In the second state of the world, $G_{2}$, ambrosia beetle $\mathrm{X}$ does not arrive to the forest stand before harvest time $T$, and the landowner therefore harvests the forest stand and incurs the replanting costs $C$ to start a new forest rotation. Thus, the net present value (NPV) of salvaged timber benefits for the $G_{1}$ (under the risk of ambrosia beetle $\mathrm{X}$ ) state of the world over an infinite time horizon is: 
$\operatorname{NPV}\left(G_{1}\right)$

$$
\begin{aligned}
= & \left\{C e^{r \varphi_{1}}+\omega\left(\varphi_{1}\right) P\left(\varphi_{1}\right) V\left(\varphi_{1}\right)\right\} e^{-r \varphi_{1}}+\left\{C e^{r \varphi_{2}}+\omega\left(\varphi_{2}\right) P\left(\varphi_{2}\right) V\left(\varphi_{2}\right)\right\} e^{-r \varphi_{1}} e^{-r \varphi_{2}} \\
& +\left\{C e^{r \varphi_{3}}+\omega\left(\varphi_{3}\right) P\left(\varphi_{3}\right) V\left(\varphi_{3}\right)\right\} e^{-r \varphi_{1}} e^{-r \varphi_{2}} e^{-r \varphi_{3}}+\cdots \\
& N P V\left(G_{1}\right)=\sum_{j=1}^{\infty}\left\{-C e^{r \varphi_{j}}+\bar{\omega}\left(\varphi_{2 j}\right) P\left(\varphi_{j}\right) V\left(\varphi_{j}\right)\right\} e^{-\sum_{j=1}^{\infty} r \varphi_{j}}, \text { if } \varphi_{j}<T
\end{aligned}
$$

where $P\left(\varphi_{j}\right)$ and $V\left(\varphi_{j}\right)$ are, respectively, the stumpage price and timber volume at salvage harvest age $\varphi_{j}$, for the $j^{\text {th }}$ rotation; $C$ is the replanting costs; and $r$ is the real discount rate. For the second state of the world $G_{2}$, the NPV of timber benefits are:

$N P V\left(G_{2}\right)$

$$
\begin{aligned}
= & \left.C+P(T) V(T) e^{-r T}+C e^{-r T}+P(2 T) V(T) e^{-r 2 T}+C e^{-2 r T}+P(3 T) V(T) e^{-r 3 T}\right)+\cdots \\
& N P V\left(G_{2}\right)=-\frac{C}{1-e^{r T}}+\sum_{j=1}^{\infty} P(j T) V(T) e^{-r j T}, \text { if } \varphi_{j}=T
\end{aligned}
$$

where $P(j T)$ is the stumpage price at stand age $T$ for the $j^{\text {th }}$ rotation, and $V(T)$ is the volume of timber at stand age $T$. We assume that the volume of timber over time $V(T)$ is a concave function, thus $V(T)^{\prime}>0$ (it is an increasing function over time until the biological age at which the forest reaches its biological maturity), and $V(T)^{\prime \prime}<0$ (it increases at an increasing rate until the inflection point, at which it continues to increase, but at a decreasing rate). Furthermore, we assume that the stumpage prices, at the moment of either salvage or harvest, are independent and identically distributed for different rotations, with mean $\bar{P}$ and variance $\sigma_{P}^{2}$. Although stumpages prices can be serially correlated, the assumption of independent and identically distributed stumpage prices, due to the long time interval between successive harvests, is well accepted in the forestry literature (Gong and Löfgren, 2007). Likewise, the normality distribution of 
stumpage prices is also widely assumed in optimal forest management studies under uncertainty (Brazee and Mendelsohn, 1988).

Intuitively, from Eqs. (2) and (4), both states of the world (i.e., salvage harvest or full harvest) cannot occur within the same forest rotation. In the case of $G_{1}$, a landowner will undertake a salvage harvest if and only if: 1) the probability of arrival of ambrosia beetle $\mathrm{X}$ is between the expected arrival bounds, upper and lower, for this insect species; and 2) the arrival of ambrosia beetle $\mathrm{X}$ occurs after a threshold time $t_{o}$, and before the harvest age $T$. This assumption is based on the fact that forest stands have a different vulnerability to pests as trees age. For example, it is well known that the susceptibility of forests stands to be attacked by wood beetles increases with age (Zhang and Zeide, 1999). Likewise, the redbay ambrosia beetle first kills large redbays in a newly colonized area, before colonizing smaller ones. If both conditions are met, a portion of the stand is salvaged, and the forest stand is replanted to start a new rotation. Otherwise, the forest is grown one extra year. Again, the conditions for $G_{1}$ are checked and the same logical process is applied-salvageable harvest or let forest grow one extra year. If the forest is allowed to grow one extra year and the stand reaches age $T$, then the landowner will harvest the forest and replant to start a new rotation. This feedback loop continues ad infinitum. Fig. 1 depicts the model's framework. Formally, the piecewise function for the forest landowner total net present value (NPVT) can be represented as:

$$
\operatorname{NPVT}(\varphi)_{y>0 ; x<T}=\left\{\begin{array}{c}
N P V\left(G_{1}(\varphi)\right), t_{o} \leq y \leq \varphi \leq x \\
N P V\left(G_{2}(\varphi)\right), \varphi=T \\
0, \text { otherwise } \\
<<\text { Insert Fig.1 here>> }
\end{array}\right.
$$




\subsection{Economic related variables}

We apply our economic model to a representative loblolly pine forest stand given its role as the main dominant commercial species in the Southern U.S. (Schultz, 1997). The growth and yield model developed by the University of Georgia Plantation Management Research Cooperative (PMRC) (Harrison and Borders, 1996) is used to determine the merchantable volume $(V(T))$ of managed loblolly pine stands. We consider three forest products based on the on stem diameter at breast height and merchantable diameter: sawtimber (stem diameter breast height $=29.2 \mathrm{~cm}$; top diameter $=17.8 \mathrm{~cm}$ ), chip-and-saw $($ stem diameter breast height $=19.1 \mathrm{~cm}$; top diameter= $15.2 \mathrm{~cm}$ ), and pulpwood (diameter breast height $=11.4 \mathrm{~cm}$; top diameter $=7.6 \mathrm{~cm}$ ). We also consider an initial site index of $20 \mathrm{~m}$ at base age 25 years and a planting density of 1500 trees ha

1. Regeneration costs $(C)$ - planting costs $\left(\$ 150 \mathrm{ha}^{-1}\right)$, site preparation $\left(\$ 494 \mathrm{ha}^{-1}\right)$, and weed control $\left(\$ 166 \mathrm{ha}^{-1}\right)$ - are assumed to be $\$ 810 \mathrm{ha}^{-1}$ (Dooley and Barlow, 2013). The real discount rate $(r)$ is set to 0.04 .

Historical real stumpage prices account for the period 1992 and 2014 (2014 base Producer Price Index, (U.S. Department of Labor Bureau of Labor Statistics, 2015) are obtained from Timber Mart South (Timber Mart South, 2014). The expected stumpage prices for sawtimber, chip-and-saw, and pulpwood are, respectively, $\bar{P}_{s}=\$ 43.8 \mathrm{~m}^{-3}, \bar{P}_{c}=\$ 31 \mathrm{~m}^{-3}$, and $\bar{P}_{p}=$ $\$ 12.3 \mathrm{~m}^{-3}$; with standard deviations of: $\sigma_{P S}^{2}=\$ 8.4 \mathrm{~m}^{-3}, \sigma_{P C}^{2}=\mathrm{U} . \mathrm{S} . \$ 5.6 \mathrm{~m}^{-3}$, and $\sigma_{P P}^{2}=\$ 2.2 \mathrm{~m}^{-3}$, respectively.

\subsection{Ambrosia beetle X related variables}

Several arrival (and establishment) rates of new forest insect species (ambrosia beetles included) in the U.S., along with urban area estimations, have been reported in recent literature (e.g., (Koch 
et al., 2011; Levine and D’Antonio, 2003). The establishment rate of a new invasive forest insect species, transported from Asia, to a city in the Southeastern U.S. was estimated to be roughly 0.002 ( $\varphi=0.002 ; 1$ every 588 years per city, accounting for the rule of tens) (Colunga-Garcia et al., 2009; Koch et al., 2011; Levine and D'Antonio, 2003). The annual U.S. national establishment rate of new alien forest insect species to be approximately $0.17(\varphi=0.17 ; 1$ every 5-6 years), based on historical merchandize imports and insect incursions data (Koch et al., 2011).

In our study we account for the fact that ambrosia beetles represent only a portion of invasive wood borers. A study by Haack (2006) indicates that, between 1985 and 2005, 10 out of $25(40 \%)$ of established beetle species (i.e., exotic bark- and wood-feeding Buprestidae, Cerambycidae, and Solytidae) in the continental U.S. have been classified as ambrosia beetles. We simulate an ambrosia beetle $\mathrm{X}$ outbreak scenario for loblolly forest stands by setting an upper bound probability of ambrosia beetle $\mathrm{X}$ arrival of $\mathrm{y}=0.07$ ( 1 every 14 years). This bound is constructed using the previously mentioned finding (40\%), as a probability multiplier that adjusts for establishment estimates of alien forest insect species that include non-ambrosia beetles $(0.17)$. Therefore, the upper bound $y=0.17 * 0.4=0.07$. Considering the wide range of the possible establishment rates of a new ambrosia beetle $\mathrm{X}$, we set the lower bound probability arrival to be $\mathrm{x}=0.04$ ( 1 every 25 years).

The decision to salvage a stand killed by a pest or to leave dead trees in the stand is primarily driven by economic factors such as preferences for timber versus non-timber benefits; the availability of harvestable timber inventory; and the degree of substitutability of salvage timber (Sims, 2013). It is also driven by the virulence of the pest or a disease, where the population growth of epidemic pests, such as the Southern pine beetle, may be effectively 
controlled by a timely salvage (Gang, 2004). In our study, focused on timber-colonizing ambrosia beetles, we assume that timber salvage is based on the severity of damage, i.e., only undamaged trees $(\omega)$ can be salvaged, and the regeneration costs after an ambrosia beetle attack are fixed and independent of salvage (Amacher et al., 2009). We assume no salvage harvesting if more than $80 \%$ of the trees are damaged. Furthermore, considering that the redbay ambrosia beetles can destroy between $90-97 \%$ of the their host trees over five years (Hanula and Mayfield, 2014; Spiegel and Leege, 2013), we assume an annual random damage intensity value between 0.18-0.19.

We also assume that stumpage prices are not affected by an initial increased supply of timber due salvage operations. Finally, we address the lack of information regarding the hypothetical ambrosia beetle $\mathrm{X}$ host age preference (loblolly tree age of vulnerability), by using the redbay ambrosia beetle as a proxy. Hanula and Mayfield (2014) suggest that redbay ambrosia beetles attack almost all redbay and swambay trees greater than $2.5 \mathrm{~cm}$ in diameter within the first 5 years of infestation. Loblolly pine trees reach said diameter growth at roughly 3 years of age, thus, $t_{o}=3$.

\subsection{Prevention scenarios}

We define alternative scenarios for our analysis. The goal of our model, for these two scenarios, is to assess the potential economic damages of ambrosia beetle $\mathrm{X}$, on loblolly pine stands, in the Southern U.S. Scenario A represents a loblolly pine stand under the status quo (current probability of arrival of ambrosia beetle X based on Koch et al. (2011)), and considers the values already defined for the economic and ambrosia beetle related variables. This scenario assumes a unit transfer of the Koch et al. (2011) estimates of new establishment rates of forest insect 
species to ambrosia beetle $X$, namely, we assume that said estimations apply 1 to 1 to ambrosia beetle X. Scenario B represents a prevention scenario based on suggested improvements to the U.S. implementation of ISPM-15 by Haack et al. (2014). The simulated improvement to the U.S. implementation of ISPM-15, discussed by Haack et al. (2014), reduces the fraudulent use of the ISPM-15 markings of WPMs without treatment. We assume an increased enforcement of fraudulent markings by: increasing random port inspections; strict re-exportation of all cargo at the expense of importer -a practice currently in place- to a limited extent, for positive detections of ambrosia beetles on ISPM-15 marked imports (APHI, 2015); and fines for companies that are found guilty of fraud. We assume that higher enforcement will lead to a $30 \%$ reduction in the probability of establishment of a new ambrosia beetle $\mathrm{X}$ from Asia, which attacks loblolly pine trees. This implies that the new lower and upper bounds, for both states of the world, for the arrival of this species are, respectively, 0.03 (every 33 years) and 0.05 (every 20 years). Although it may be considered a conservative estimate, our rationale is based on the fact that despite some regulatory efforts, exotic insects are difficult to detect and several of these species may still be introduced in the U.S. (Aukema et al., 2010). Finally, Scenario $C$ represents a situation in which the arrival of ambrosia beetle $\mathrm{X}$ is fully controlled, thus a loblolly pine stand is not affected by this invasive pest $(\operatorname{Pr}(\varphi)=0)$.

For all scenarios, and by using the Eqs. (2), (4), and (5), we simulate the arrival and economic impacts (NPV) of ambrosia beetle X on a loblolly pine forest stand for one thousand rotations $(j)$ to mimic an infinite time horizon.. Due to the stochastic nature of our model, we assume harvest ages $T$ between 19 and 27 years (initial harvest ages), which are in the range of harvest ages for loblolly pine forests (Susaeta et al., 2014a; 2014b). This range of ages represents the initial harvest ages when the arrival of ambrosia beetle is fully controlled 
$(\operatorname{Pr}(\varphi)=0$, Scenario $C)$. Our economic simulations also provide the economic impacts at the actual harvest ages for those scenarios that include the probability of arrival of ambrosia beetle $\mathrm{X}$ (Scenarios A and B). We employ use an Excel-based spreadsheet model (MacDonald, 2010) to compute our simulations and economic analysis due to the easiness in analyzing data (Nunes et al., 2015).

\section{Results and discussion}

On average, for the whole range of initial harvest ages, the net present value of timber harvests (NPVT) of a loblolly forest stand is $\$ 5325.3 \mathrm{ha}^{-1}$ and the actual harvest age is 17.8 years (Table 1). Between the initial harvest ages of 19 and 22 years, the NPVT of timber benefits shows an increasing trend at an average rate of about $2 \%$ - the variability (coefficient of variation) of the economic rents also increases. For 23 years onwards (age-fixed harvest ages), the timber economic rents marginally decrease between subsequent harvest ages at an average rate of $0.9 \%$, yet their variability shows an unclear trend. The actual timing of harvest increases with longer initial harvest ages. Although our simulations show that NPVT tend to decrease with longer harvest ages, a forest landowner will delay the actual harvest age in the absence of a major pest, and thus, attempt to realize higher economic rents.

\section{$<<$ Insert Table 1 here >}

Consistent with expectations, a decrease in the probability of arrival of ambrosia beetle $\mathrm{X}$ on loblolly pine stands implies higher economic revenues for forest landowners (Scenario B). On average, for all harvest ages, the NPVT of a loblolly pine forest stand is $\$ 6116.4 \mathrm{ha}^{-1}$, a $15 \%$ increase compared to the baseline arrival for ambrosia beetle $\mathrm{X}$ (Scenario A) (Table 1). This reflects a total economic loss, for forest landowners, of $\$ 791.1 \mathrm{ha}^{-1}$. Contrary to Scenario A, the NPVT of timber benefits with a reduced impact of ambrosia beetle $\mathrm{X}$ indicates a fluctuating 
trend after fixed harvest age of 23 years, and also, a fluctuating variability of NPVT of the timber benefits along all initial fixed harvest ages. The actual harvest ages also increase to 19.0 years, with an increasing variability (with the exception of the fixed harvest age 26 years), with a reduced arrival rate of ambrosia beetle $\mathrm{X}$ (Table 1). As the forest stand grows without infestations by ambrosia beetle $\mathrm{X}$, more wood is produced, and forest landowners are able to realize higher timber economic benefits at the time of harvest. The difference in economic rents between both scenarios is accentuated with longer initial harvest ages: between ages 25 and 27 years, the NPV, on average, is $16 \%$ greater than the NPV with no prevention of ambrosia beetle $\mathrm{X}$ invasion.

If the Southeastern U.S. were to be remain free of ambrosia beetle $\mathrm{X}(\operatorname{Pr}(\varphi)=0)$, the NPV of loblolly pine timber benefits would range between $\$ 7806.9-8246.7 \mathrm{ha}^{-1}$ for the entire range of harvest ages (Table 1). On average, the economic losses for forest landowners with no control or partial control of ambrosia beetle $\mathrm{X}$ would be roughly \$2772.3-1981.2 $\mathrm{ha}^{-1}$, respectively, representing a fall of around $33 \%$ and $24 \%$ in the NPVs. These estimates, multiplied by the total number of commercial loblolly pine forest hectares in the region (more than 6.3 million ha according to Schultz (1997)) reveal the upper-bound cost estimates of the status quo and partial control of ambrosia beetle $\mathrm{X}, \$ 17$ billion and $\$ 13$ billion, respectively. Thus implying that a $30 \%$ reduction in the probability of establishment of a new ambrosia beetle $\mathrm{X}$ from Asia, affecting loblolly pines in the Southeastern U.S., could result in roughly $\$ 4.6$ billion in damage prevention.

If we account for the fact that approximately $64 \%$ of all merchantable loblolly pine stock, in the Southern U.S., is own by non-industrial private forest landowners (Schultz, 1997) then a partial control of arrival could roughly save $\$ 3$ billion in direct production losses for them in the 
Southeast. It is important to reiterate that this figure is also an upper-bound estimate, as it assuming that all hectares in the region experience the same probability of an ambrosia beetle $\mathrm{X}$ outbreak, and are managed under the assumptions depicted in our model.

Our numerical results indicate a severe impact of a hypothetical infestation of an exotic pine-infesting ambrosia beetle on the economic value of U.S. southeastern pines. Furthermore, this would have several implications for other timber-related economic sectors, consistent with other studies of invasive species that affect forests. For example, Aukema et al. (2011) estimated the economic impact of currently established invasive wood borers in the U.S., using a partial equilibrium framework, which roughly annually accounted for $\$ 1.7$ billion in local governments expenditures, and approximately $\$ 830$ million year $^{-1}$ is lost in residential property values. Total

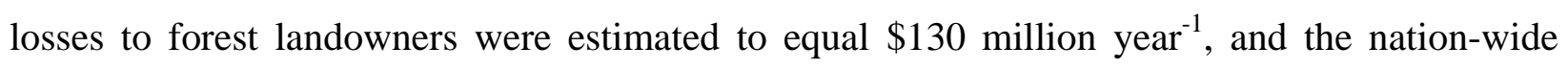
economic impact of timber losses were estimated at roughly $\$ 2.1$ billion year $^{-1}$ (Pimentel et al., 2005).

Regulations that help prevent the introduction of nonindigenous species are critical to maintain the health of the U.S. forests (Magarey et al., 2009). Furthermore, the interception of the nonindigenous pests at border ports becomes imperative since the typical management option of established pests is the eradication or plans to slow the spread of the pest which are generally expensive and rarely successful (McCullough et al., 2006). Internalizing preventative measures for ambrosia beetle $\mathrm{X}$ would not only increase forestland values, but it may also help improve trade and U.S. welfare. An example is the USDA Forest Service EDRR program which monitors new forest pest arrival with hundreds of traps in nearly half of the States (Rabaglia et al., 2008). In spite of recent budgetary cuts, the EDRR program continues to receive agency and budgetary support ( $\sim 300000$ for 2014) for the program. Given that the average economic losses for forest 
landowners with no control of ambrosia beetle $\mathrm{X}$ would be approximately $\$ 791.1 \mathrm{ha}^{-1}$, this implies that saving just 379 ha of forest land would make EDRR economically effective (with avoided damages equaling the entire budgetary allocation of EDRR program, nationwide).

Currently, several factors are limiting the effectiveness of policy instruments to eliminate or reduce the invasions of wood borers. Examples of such factors include unintentional noncompliance with ISPM-15, fraud, and post-treatment colonization (Haack et al., 2014), which remain significant concerns. Stringent policy enforcement and robust support from the forest landowner and land manager community would be crucial to effectively reduce the hypothetical damage of ambrosia beetle $\mathrm{X}$ on forestry and other sectors. In spite of these limiting factors, it is worth noting that ISPM-15 guidelines were recently revised to reduce infestations of wood borers after treatment, namely, the new rules now encourage the elimination of bark patches of $50 \mathrm{~cm}^{2}$ in surface area and $3 \mathrm{~cm}$ wide (FAO, 2011; 2009).

\section{Conclusions}

We employ a forest stand-level simulation model to assess the economic impacts of a hypothetical invasion of ambrosia beetle $\mathrm{X}$ on the optimal forest management of loblolly pine stands. Our results indicate that an increase in the enforcement of international phytosanitary standards for preventing the establishment of ambrosia beetle $\mathrm{X}$ even as low as $30 \%$ arrival reduction would increase economic revenue and optimal harvest age by $\$ 791 \mathrm{ha}^{-1}$ and 1.2 years, respectively. Our findings also suggest that the economic gains associated with improvements to current preventative measures such as the reinforcement of ISPM-15 (around $\$ 4.6$ billion dollars), would greatly outweigh the cost of programs that reduce the expected arrival of exotic ambrosia beetles (e.g. EDRR program). 
These findings also highlight the importance of further research in this area. As more knowledge about the relationship of this class of invasive species (ambrosia beetles) and commercially important tree species is obtained, the incorporation of silvicultural techniques such as the management of tree planting density or the use of biological control become additional factors that can be included in this economic framework. We caution that our analysis does not consider the impacts of this invasive species on non-timber ecosystem services. This is particularly relevant in the Southeastern U.S. where the pine forests play a pivotal role in: sequestering regional greenhouse gases (Han et al., 2007); providing water quality; supporting biodiversity, wildlife habitat and recreation (Kreye et al., 2014). Thus, our results should be treated as providing a significant underestimate of the potential economic damages to both landowners and society from this invasive species. As such, an important area for future research is the consideration of damages of ambrosia beetles to non-timber benefits, not only to assess the real magnitude of costs, but also to inform the design of feasible and economically-effective control policies that ensure the sustainability of forestlands in the U.S. Finally, we caution that our model assumes that forest landowners are risk-neutral to the arrival of this invasive species. A more robust analysis, which considers alternative levels of risk preference and implications for loblolly forest management, is another important area for further study.

\section{Acknowledgements}

This work is supported by the USDA Farm Bill agreement 14-8130-0377-CA, and the USDA-FS Cooperative agreements 14-CA-11330130-032 and 12-CA-11420004-042. 


\section{References}

Adams, D.C., Lee, D.J., 2013. Economics of invasive plant management, in: Jose, S., Batish, D.R., Kohli, R.K. (Eds.), Invasive Plant Ecology. CRC Press, pp. 239-258.

Amacher, G.S., Ollikainen, M., Koskela, E., 2009. Economics of Forest Resources. MIT Press, London, England.

APHI, 2015. APHIS adopts international standards on wood packaging materials [WWW Document]. USDA Anim. Plant Heal. Insp. Serv. URL https://www.aphis.usda.gov/wps/portal/aphis/ourfocus/planthealth/sa_import/sa_wood_pac king/sa_hot_topics/ct_wood_packing/!ut/p/a0/04_Sj9CPykssy0xPLMnMz0vMAfGjzOK9_ D2MDJ0MjDzd3V2dDDz93HwCzL29jAx8TfULsh0VAY_1WkE!/ (accessed 1.10.15).

Aukema, J.E., Leung, B., Kovacs, K., Chivers, C., Britton, K.O., Englin, J., Frankel, S.J., Haight, R.G., Holmes, T.P., Liebhold, A.M., McCullough, D.G., Von Holle, B., 2011. Economic impacts of non-native forest insects in the continental United States. PLoS One 6, e24587.

Aukema, J.E., McCullough, D.G., Von Holle, B., Liebhold, A.M., Britton, K., Frankel, S.J., 2010. Historical accumulation of nonindigenous forest pests in the continental United States. Bioscience 60, 886-897.

Bateman, C.C., Hulcr, J., Black, A., Bo, W., 2014. Protecting American pine forests: an assessment of potentially invasive beetle-fungus pathogens in Asia. In: Gandhi, K., Hulcr, J., Eds.), 56th Annual Southern Forest Insect Work Conference. Charleston, SC, pp. 47.

Brazee, R., Mendelsohn, R., 1988. Timber harvesting with fluctuating prices. For. Sci. 34, 359372. 
Colunga-Garcia, M., Haack, R.A., Adelaja, A.O., 2009. Freight transportation and the potential for invasions of exotic insects in urban and periurban forests of the United States. J. Econ. Entomol. 102, 237-246.

Costanza, J. K., Hulcr, J., Koch, F. H., Earnhardt, T., McKerrow, A. J., Dunn, R. R., Collazo, J. A., 2012. Simulating the effects of the southern pine beetle on regional dynamics 60 years into the future. Ecol. Model. 244, 94-103.

Dooley, E., Barlow, R., 2013. 2012 Cost and cost trends for forestry practices in the South. For. Landowner. October, 22-29.

FAO, 2003. International standards for phytosanitary measures: guidelines for regulating wood packaging material in international trade. FAO publication No. 15. Rome, Italy, $17 \mathrm{p}$.

FAO, 2009. International standards for phytosanitary measures: revision of ISPM No. 15, regulation of wood packaging material in international trade. FAO ISPM No.15, Rome, Italy, $16 \mathrm{p}$.

FAO, 2011. Guide to the implementation of phytosanitary standards in forestry. FAO forestry paper 164, Rome, Italy, $101 \mathrm{p}$.

Gong, P., Löfgren, K.G., 2007. Market and welfare implications of the reservation price strategy for forest harvest decisions. J. For. Econ. 13, 217-243.

Haack, R. A.,2006. Exotic bark- and wood-boring Coleoptera in the United States: recent establishments and interceptions. Can. J. For. Res.36, 269-288.

Haack, R. A., Britton, K.O., Brockerhoff, E.G., Cavey, J.F., Garrett, L.J., Kimberley, M., Lowenstein, F., Nuding, A., Olson, L.J., Turner, J., Vasilaky, K.N., 2014. Effectiveness of the international phytosanitary standard ISPM no. 15 on reducing wood borer infestation rates in wood packaging material entering the United States. PLoS One 9, e96611.

Haack, R. A., Petrice, T.R., 2009. Bark- and wood-borer colonization of logs and lumber after heat treatment to ISPM 15 specifications: the role of residual bark. J. Econ. Entomol. 102, $1075-1084$.

Han, F.X., Plodinec, M.J., Su, Y., Monts, D.L., Li, Z., 2007. Terrestrial carbon pools in southeast and south-central United States. Clim. Change 84, 191-202.

Hanula, J.L., Mayfield, A.E., 2014. Redbay ambrosia beetle (Xyleborus glabratus Eichhoff) (Coleoptera: Curculionidae). In: Van Driesche, R., Reardon, R. (Eds.), The Use of Classical Biological Control to Preserve Forests in North America. FHTET-2013-12. USDA Forest 
Service, Forest Health Technology Enterprise Team. Morgantown, West Virginia, pp. 299311.

Harrison, D., Borders, B., 1996. Yield prediction and growth projection for site-prepared loblolly pine plantations in the Carolinas, Georgia, Alabama and Florida. PRMC tenchical report 1996-1. Athens, GA, 59 p.

Houlahan, J.E., Findlay, C.S., 2004. Effect of Invasive plant species on temperate wetland plant diversity. Conserv. Biol. 18, 1132-1138.

Hulcr, J., Lou, Q.-Z., 2013. The redbay ambrosia beetle (Copeoptera: Curculionidae) prefers Lauraceae in its native range. Florida Entomol. 96, 1595-1597.

Hulcr, J., Mogia, M., Isua, B., Novotny, V., 2007. Host specificity of ambrosia and bark beetles (Col., Curculionidae: Scolytinae and Platypodinae) in a New Guinea rainforest. Ecol. Entomol. 32, 762-772.

Keller, R.P., Perrings, C., 2011. International policy options for reducing the environmental impacts of invasive species. Bioscience 61, 1005-1012.

Knight, K.S., Brown, J.P., Long, R.P., 2013. Factors affecting the survival of ash (Fraxinus spp.) trees infested by emerald ash borer (Agrilus planipennis). Biol. Invasions 15, 371-383.

Koch, F.H., Yemshanov, D., Colunga-Garcia, M., Magarey, R.D., Smith, W.D., 2011. Potential establishment of alien-invasive forest insect species in the United States: where and how many? Biol. Invasions 13, 969-985.

Kreye, M., Adams, D., Escobedo, F., 2014. The value of forest conservation for water quality protection. Forests 5, 862-884.

Lee, D.J., Adams, D.C., Kim, C., 2009. Managing invasive plants on public conservation forestlands: Application of a bio-economic model. For. Policy Econ. 11, 237-243.

Levine, J.M., D'Antonio, C.M.D., 2003. Forecasting biological international trade invasions with increasing international trade. Conserv. Biol. 17, 322-326.

MacDonald, M., 2010. Excel 2010: The Missing Manual, first edit. ed. O'Reilly Media, Sebastopol, CA.

Magarey, R.D., Colunga-Garcia, M., Fieselmann, D. A., 2009. Plant biosecurity in the United States: roles, responsibilities, and information needs. Bioscience 59, 875-884. 
Maner, M.L., Hanula, J.L., Braman, S.K., 2013. Gallery productivity, emergence, and flight activity of the redbay ambrosia beetle (coleoptera: curculionidae: scolytinae). Environ. Entomol. 42, 642-647.

Mann, R., Hulcr, J., Peña, J., Stelinski, L., 2011. Redbay ambrosia beetle Xyleborus glabratus Eichhoff ( Insecta : Coleoptera: Curculionidae: Scolytinae ) EENY491, Entomology and Nematology Depatrment, University of Florida. Gainesville, FL, 6 p.

McCullough, D.G., Work, T.T., Cavey, J.F., Liebhold, A.M., Marshall, D., 2006. Interceptions of nonindigenous plant pests at US ports of entry and border crossings over a 17-year period. Biol. Invasions 8, 611-630.

North American Xyleborini, 2015. Ambrosia symbiosis. [WWW document]. URL http://www.ambrosiasymbiosis.org/northamericanxyleborini/list.html (accessed 9.3.15).

Nunes, C.A., Alvarenga, V., Sant'Ana, A., Santos, J., Granato, D., 2015. The use of statistical software in food science and technology: advantages, limitations and misuses. Food Res. Int. 75, 270-280.

Oswalt, S.N., Smith, W.B., Miles, P.D., Pugh, S. A., 2014. Forest Resources of the United States, 2012: a technical document supporting the Forest Service 2015 update of the RPA Assessment. U.S. Department of Agriculture, Forest Service, Gen. Tech. Rep. WO-91. Washington, DC, $218 \mathrm{p}$.

Pimentel, D., Zuniga, R., Morrison, D., 2005. Update on the environmental and economic costs associated with alien-invasive species in the United States. Ecol. Econ. 52, 273-288.

Rabaglia, R.J., Duerr, D., Acciavatti, R., Ragenovich, I., 2008. Early detection and rapid response for non-native bark and ambrosia beetles. U.S. Department of Agriculture, Forest Service, Forest Health. Washington, DC 12 p.

Rabaglia, R.J., Dole, S. A., Cognato, A.I., 2006. Review of American xyleborina (Coleoptera: Curculionidae: Scolytinae) occurring north of Mexico, with an illustrated key. Ann. Entomol. Soc. Am. 99, 1034-1056.

Reed, W., 1984. The effects of the risk of fire on the optimal rotation of a forest. J. Environ. Econ. Manage. 11, 180-190.

Roques, A., Fan, J., Courtial, B., Zhang, Y., Yart, A., Auger-Rozenberg, M.-A., Denux, O., Kenis, M., Baker, R., Sun, J., 2015. Planting sentinel European trees in Eastern Asia as a novel method to identify potential insect pest invaders. PLoS One 10, e0120864. 
Schultz, R., 1997. Loblolly Pine: The ecology and culture of loblolly pine (Pinus taeda L.). U.S. Department of Agriculture, Forest Service Handbook 713. Washington, DC, 493 p.

Shear, M.D., 2015. The Trans-Pacific partnership: questions and answers. New York Times [WWW document]. URL http://www.nytimes.com/2015/06/17/us/questions-and-answersabout-the-trans-pacific-partnership.html?_r=0 (accessed 10.10.15).

Sims, C., 2013. Influencing natural forest disturbance through timber harvesting: tradeoffs among disturbance processes, forest values, and timber condition. Am. J. Agric. Econ. 95, 992-1008.

Sobel, L., Lucky, A., Hulcr, J., 2015. An ambrosia beetle Xyleborus affinis Eichhoff , 1868 ( Insecta : Coleoptera : Curculionidae : Scolytinae ). EENY491, Entomology and Nematology Depatrment, University of Florida. Gainesville, FL, 5 p.

Spiegel, K.S., Leege, L.M., 2013. Impacts of laurel wilt disease on redbay (Persea borbonia (L.) Spreng.) population structure and forest communities in the coastal plain of Georgia, USA. Biol. Invasions 15, 2467-2487.

Susaeta, A., Chang, S.J., Carter, D.R., Lal, P., 2014b. Economics of carbon sequestration under fluctuating economic environment, forest management and technological changes: An application to forest stands in the southern United States. J. For. Econ. 20, 47-64.

Susaeta, A., Alavalapati, J.R.R., Carter, D.R., 2009. Modeling impacts of bioenergy markets on nonindustrial private forest management in the southeastern United States. Nat. Resour. Model. 22, 345-369.

Susaeta, A., Carter, D.R., Adams, D.C., 2014a. Sustainability of forest management under changing climatic conditions in the southern United States: adaptation strategies, economic rents and carbon sequestration. J. Environ. Manage. 139, 80-7.

Timber Mart South, 2014. Timber Mart South market newsletter: quarterly stumpage prices 1992-2015. Athens, GA.

U.S. Congress Office of Technology Assessment, 1993. Harmful non-indigenous species in the United States. OTA-F-565. Washington, DC, 391 p.

U.S. Department of Labor Bureau of Labor Statistics, 2015. Producer price index industry data [WWW Document]. URL http://data.bls.gov/cgi-bin/dsrv (accessed 5.9.15).

Zhang, Y., Zeide, B., 1999. Which trees and stands are attacked by the southern pine beetle? South. J. Appl. For. 23, 217-223. 


\section{Figure Captions}

Fig. 1. Logic framework for the economics of ambrosia beetle $\mathrm{X}$ arrival on loblolly pine stands. 
Table 1. Net present value (NPV) and actual harvest years of a loblolly pine stand under no control (Scenario A), partial control (Scenario B) and full control (Scenario C) of ambrosia beetle $\mathrm{X}$.

\begin{tabular}{|c|c|c|c|c|c|c|c|c|c|}
\hline \multicolumn{10}{|c|}{$\operatorname{NPV}\left(\$ \mathrm{ha}^{-1}\right)$} \\
\hline Scenario A & $19^{a}$ & 20 & 21 & 22 & 23 & 24 & 25 & 26 & 27 \\
\hline Mean & 5130.9 & 5279.8 & 5329.4 & 5459.7 & 5423.3 & 5358.8 & 5335.9 & 5322.2 & 5287.8 \\
\hline St dev. & 1753.1 & 1865.9 & 1879.5 & 1932.5 & 2002.1 & 1963.8 & 1892.0 & 1941.6 & 1881.9 \\
\hline Coeff. Var. & 0.34 & 0.35 & 0.35 & 0.35 & 0.37 & 0.37 & 0.35 & 0.36 & 0.36 \\
\hline \multicolumn{10}{|l|}{ Scenario B } \\
\hline Mean & 5884.8 & 6039.2 & 6131.9 & 6205.2 & 6106.1 & 6179.3 & 6244.1 & 6150.7 & 6106.3 \\
\hline St dev. & 1646.7 & 1722.8 & 1643.2 & 1742.8 & 1760.0 & 1826.7 & 1721.7 & 1645.8 & 1683.6 \\
\hline Coeff. Var. & 0.28 & 0.29 & 0.27 & 0.28 & 0.29 & 0.30 & 0.28 & 0.27 & 0.28 \\
\hline \multicolumn{10}{|l|}{ Scenario C } \\
\hline Mean & 7806.9 & 7999.7 & 8115.3 & 8229.1 & 8241.8 & 8246.6 & 8174.3 & 8123.9 & 7941.0 \\
\hline St dev. & 822.9 & 795.8 & 892.4 & 922.6 & 921.6 & 949.9 & 977.9 & 997.0 & 1021.3 \\
\hline Coeff. Var. & 0.11 & 0.10 & 0.11 & 0.11 & 0.11 & 0.12 & 0.12 & 0.12 & 0.13 \\
\hline \multicolumn{10}{|c|}{ Actual harvest age (years) } \\
\hline \multicolumn{10}{|l|}{ Scenario A } \\
\hline Mean & 15.8 & 16.3 & 16.9 & 17.4 & 17.9 & 18.3 & 18.8 & 19.3 & 19.6 \\
\hline St dev. & 0.59 & 0.67 & 0.75 & 0.86 & 0.94 & 1.00 & 1.08 & 1.27 & 1.32 \\
\hline Coeff. Var. & 0.04 & 0.04 & 0.04 & 0.05 & 0.05 & 0.05 & 0.06 & 0.07 & 0.07 \\
\hline \multicolumn{10}{|l|}{ Scenario B } \\
\hline Mean & 16.5 & 17.1 & 17.8 & 18.4 & 19.0 & 19.6 & 20.2 & 20.8 & 21.2 \\
\hline St dev. & 0.53 & 0.61 & 0.72 & 0.80 & 0.91 & 0.95 & 1.12 & 1.12 & 1.29 \\
\hline Coeff. Var. & 0.03 & 0.04 & 0.04 & 0.04 & 0.05 & 0.05 & 0.06 & 0.05 & 0.06 \\
\hline
\end{tabular}

${ }^{a}$ Gray numbers represent the initial harvest ages. 


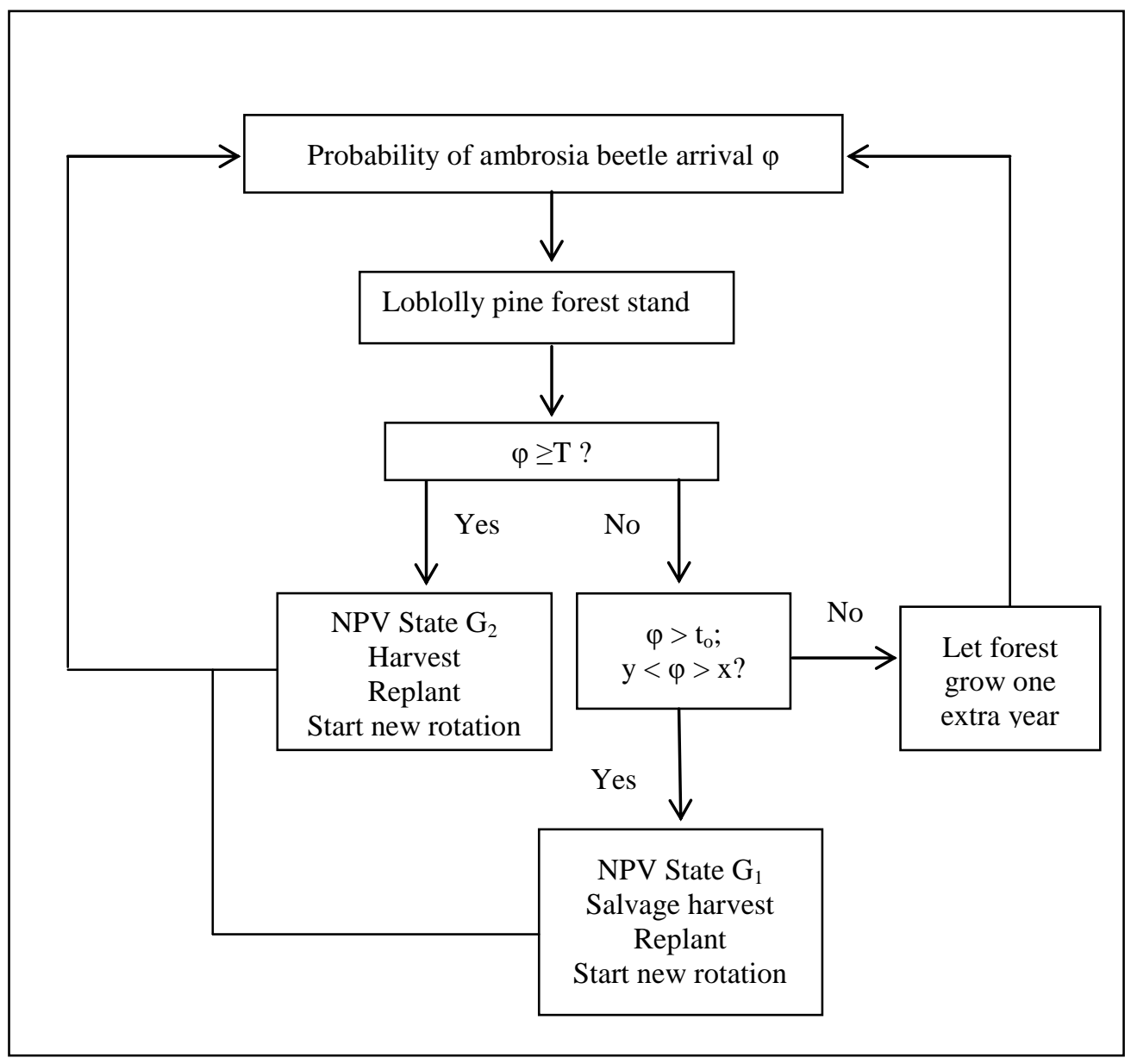

